\title{
CitIZENSHIP, ACTIVISM AND PARTICIPATION ON THE INTERNET: BRAZILIAN EXPERIENCES
}

\author{
Caroline Kraus Luvizotto
}

\begin{abstract}
A number of social and political actions have been strengthened and potentiated by internet support, with use of its network architecture to disseminate information, promote collective discussion and support activism. In order to discuss how internet tools can contribute to political and social participation in Brazil, were identified on two websites: Vote na Web (Vote on the Web), which is privately owned, and Participatório: Observatório Participativo da Juventude (Participatory: Youth Participatory Surveillance), which is the result of an initiative by the government through the Secretaria Nacional da Juventude - SNJ (National Youth Secretariat). From these examples, this study aims to analyze the use of the internet for the creation, organization and dissemination of social and political participation and online activism in Brazil. It is understood that the websites are limited and that online tools are not used to their full potential. However, considering a context of citizenship and online participation, it is possible to verify that the architecture of those websites encourages participation - even without civic engagement - and can be a step forward towards an enhanced civic practice.
\end{abstract}

Keywords

Political and social participation; activism; internet; Vote na Web; Participatório

\section{INTRODUCTION}

Contemporary social dynamics is stimulated by the participation of individuals in political and social movements and projects that form sources of innovation and patterns, generating democratic and civil knowledge, justifying analyses that emphasize the focus on networks of articulation and communication established by the subjects in their daily practice. Therefore, the study of such networks becomes essential to understand the factors that contribute to trigger learning and the emergence or intensification of participation culture values. Participation is a collective social action that has its genesis in a series of characteristics, among which we can highlight its shared strategies, organization, historicity, ties and identities. These characteristics added to a society project lead the social actors to approach these collective actions and act actively or occasionally with social movements, the political decision-making spaces and the most diverse contexts where a democratic and civil action is necessary.

A number of sociopolitical actions have been strengthened and potentiated by internet support, with use of its network architecture to disseminate information and promote collective discussion. From this tool, it was possible to propose and organize actions and broaden the channels of participation. Pereira (2011, p. 16) explains that the potential of the internet focuses on "reaching individuals, at first with no political links 
to the classic institutions of civil society organization, who are willing to participate in specific actions of protest, cybernetic or not, provided that they are 'properly' convinced to do it, and presenting some identity with their interests and perceptions of the world". It stands out here that this engagement or linkage is fundamentally based on the freedom "of the non-formal militant to engage when and wherever he wants without the high costs of formal participation". The author also highlights that the cyber actions may or may not extend to a participation outside the internet, "but this is not a presupposition required by the movements, and the non-participation does not require any form of penalty" (Pereira, 2011, p. 16).

Therefore, the fundamental importance of the internet as a tool for dissemination of informational content of political and social nature, as well as a support to organize collective actions, is recognized. To understand how the internet tools and digital media contribute to this scenario of political and social participation in Brazil, we identified two websites: the first, privately owned, characterized by a channel with participation of citizens in government issues, aiming to strengthen the struggle for citizenship and social justice: the Vote na Web (Vote on the Web); the other, presenting a government initiative, launched by the Secretariado Nacional da Juventude (SNJ) (National Youth Secretariat), the Participatório: Observatório Participativo da Juventude (Participatory: Youth Participatory Surveillance), which aims to produce information on youth from the participation of young people, being a channel for them to participate in government issues. From the examples of the Vote na Web and Participatório, this study aims to reflect on the use of the internet for the creation, organization and dissemination of political and social participation and online activism in Brazil.

It can be said that the collective actions are healthy within a plural political and social environment as the Brazilian and design political actors who will demand the government the realization of civil, political and social rights guaranteed by law. It is a component resulted from maturing democracies. "The change in understanding the organization and the social collective action occurred mainly as a result of transformations in the international political scene", points out Machado (2007, p. 254), which emphasizes the observed intensification of forces verified when "with the end of the Cold War and the emergence of symbiosis between western democracy and capitalism, social movements gradually came to be seen as important social actors for the promotion of civil rights and citizenship" (Machado, 2007, p. 254).

Classical sociology adds complexity to the study of collective social actions. According to Max Weber (1978, p. 139), social action must be understood as every action "with proper sense, directed to the action of others". The sense is given by the actor to the action, which leads him to choose principles, procedures and purposes. Social action differs from all other forms of action because its agent is aware of what he chooses, and actions can be assessed according to the degree of awareness of the agent about its meaning. Shared identities can strengthen the feeling of belonging, which would tend to encourage participation. The complexity arises when we seek to understand the complicated relationship among social movements, identity and participation. The Brazilian 
researcher Cicilia Peruzzo (2013) points out that such actions indicate the existence of a collective organization that implies shared identities and mobilization and communication strategies.

The structure of the internet network enables the articulation of social actors in inter and correlated ways. According to the Spanish sociologist Manuel Castells (2006, pp. 108-109), this paradigm presents certain essential characteristics: "information is its raw material, the effects of new technologies have high penetration, predominance of logic networks, flexibility, increasing convergence of technologies".

The features of Web 2.o facilitated the creation and circulation of content to internet users, who can act as readers, authors, producers and editors of multimedia information content. The user is no longer thought as a passive agent, but as a content developer. The second generation of online tools, characterized by digital media, enhances forms of publications, sharing and organizing information, and expand the spaces for collaboration among participants. It intensifies the promise of creating a collective intelligence, or the collective construction of knowledge. Through interaction, communities formed around specific interests will be able to support a cause, discuss individual or collective relevant topics, lead public opinion to reflect and disseminate political and social information (Valente \& Mattar, 2007).

Web 2.0 tools are organizing and promoting the development of new digital media and virtual social networks, as the costs of mobilization of social actors are reduced. The policy action through technologies "becomes cheaper, faster, and therefore more accessible to groups that are not part of the institutionalized political system", according to Pereira (2011, p. 14). The networks that integrate this logic have coordinating and mobilizing potential and, according to Brazilian sociologist Ilse Scherer-Warren (2006, p 115), "for being multiform, they approach social actors - from the local to the global levels, from different types of organizations - and enable the dialogue of diversity of interests and values".

These tools are redesigning and redefining the creation and dissemination of online social activism, creating interesting new, more personalized, social and flexible transmission opportunities, with an information sharing nature. Through the internet, the ideological censorship and editorial policies of traditional media, such as television, radio and print media can be overcome. With the new ICT (Information and Communication Technologies), it is expected, according to their potential, to disseminate the information contents with maximum exchanges, seeking interaction, support, criticism, suggestions that, in the case of social activism, means to express, by its actors, in the most diverse and comprehensive form, the struggle for the concretization of citizenship (Moraes, 2000).

In contemporary society, the organization of social actors in virtual communities and social networks "has allowed political activism to be organized so that time, financial, spatial, ideological and identity constraints can be overcome, contributing to the expansion of activities to levels a few sometimes imagined before" (Pereira, 2011, p. 19). This scenario, in which information and communication plays a decisive role, is produced from the interaction in virtual social networks and use of digital media, which 
connects people and social movements, can have a remarkably democratic nature.

\section{PARTICIPATION, ACTIVISM AND INTERNET}

The social changes occurred especially in the last three decades were caused by severe inclusion of information technologies in the society. These changes have led to the spread of information and communication in a very dynamic way and have even raised the connection of society through a large network. For this reason, some scholars point information as the raw material of this society, so it is possible to quote Castells (2006, p. 21) when he states that "the generation, processing and transmission of information becomes the main source of productivity and power".

Castells (2006) highlights the penetrability of the effects of new technologies. This penetrability is due to the fact that communication is a characteristic of the human being and that this would be shaped by technological means. The organization of the network is also a characteristic of this society, that is, a logic that seems ideal to collective communication. This logic organizes the communication in order to keep it flexible. Flexibility is another feature described by this author. On this, he states that the processes are reversible without the destruction of what is already done, which requires a constant networking system reorganization capacity. Finally, there is the convergence of specific technologies into a highly integrated system. In this case, the integration of technologies in several areas of knowledge are configured as constant for the production of knowledge (Luvizotto \& Carniel, 2013).

Conversation and discussion environments have become an important subject of research, once communication spaces reveal social traits and dynamics. The concept of participation exists before the internet, but the technical possibilities of this medium broadened the debate and gave rise to new discussions environments and analysis methodologies.

Participation and its forms change according to the possibility of reaching different social subjects who identify themselves with a particular cause, or are simply aware of their role as citizens and the need to participate. Thus, it is discuss the concepts of participation before and after the internet, specifically with the advent of Web 2.0.

"Participation" has a broad sense, it can be cultural, social or political. For Bordenave (1983, p. 23), "participation is to be part, take part or have part". For him, it is useless "to be part" without "taking part", such as someone who is part of a group but does not take part of the group's decisions. Participation is linked to activity and engagement. Participation would be innate to human beings because of their creative and rational needs and democracy would be a state of participation (Bordenave, 1983). For Demo (1996, pp. 19-20), "participation implies commitment, involvement, presence in actions sometimes risky and even reckless". In this sense, we can say that the exercise of citizenship passes directly through the participation of the people and their demands.

It is possible to see that current generations exert part of their expressive rights through the Internet. Web 2.0 serves as a major attraction for the articulation of social 
movements, because the collective interaction through communities formed around specific interests, to support causes, and to discuss individual issues or issues of collective relevance, thus leading the public reflection and disseminate political and social information, is possible (Luvizotto, 2015).

Considering the internet and digital media, the forms of communication and information consumption have changed, being no longer unilateral - nature of the mass media - and become more participative and democratic. Even if it is limited, considering the problems of access to network, accessibility, usability and user's knowledge, the internet enables the participation and interaction among people, being a fast and practical form of communication without geographical barriers. This online environment changed the way subjects and social groups express their political and social demands. In this context, the activism appears with privileged space on the internet and the role of social movements becomes more comprehensive, occupying online spaces (on the internet) and offline (on the streets).

It is understood activism as taking part in an action aiming at a social transformation. It means to participate, act, discuss, decide and implement actions defending an idea, a cause or ideology. This idea can be political, social, religious or of any identity feature. Thus, there are several ideas that can motivate an activist action as the environmental, feminist, black movement, LGBTT (Lesbians, Gays, Bisexuals, Transvestites and Transgenders) movement, legal activism, anti-capitalism causes, among others. For Mansbridge (1990, p. 229) "activists are those who participate in public life beyond the election periods. They are those who identify with a social movement, which engage with its causes and support them effectively".

The actuation of social movements, which Brazilian sociologist Maria da Glória Gohn (2003, p. 13) defines as "collective social actions presenting social, political and cultural characteristics that enable different forms of the population to organize and express its demands", is a form of activism. The actions of social movements can be expressed in the form of protests, strikes, manifestations, occupations of public or private spaces, and may use violence or not. For Young (2001, p. 672), "more than the agreement among those who support the existing power structures, it is necessary to confront them in public spaces through public manifestations, such as protest walks, boycotts and other direct actions". The peaceful work done by social organizations and civil associations, structured NGOs or groups fighting and working for a cause, without necessarily being part of a social movement, are also forms of activism.

Reflecting on social mobilization, stands out Scherer-Warren, who presents an organization of civil society mobilized at three levels:

- The first level - local activism: community movements and NGOs fighting for "social or cultural causes of daily life" (Scherer-Warren, 2006, p. 110). As an example of this level, the author highlights the cores of the landless, homeless, picketers movements, solidarity enterprises and neighbourhood associations.

- The second level - inter-organizational organizations: "civil society forums, the national NGO associations and networks of networks" (Scherer-Warren, 2006, p. 111), which are linked to empower 
civil society. At this level there is the necessary mediation for more institutionalized partnerships between the society and the State.

- The third level - mobilization in the public sphere: the articulation of all these social actors who seek something beyond conciliatory institutional organization and depart for large manifestations, aiming to have media visibility and to apply political pressure (Scherer-Warren, 2006, p. 111). As an example of the third level, it is indicated the Slutwalk, the LGBTT Pride Parade, and the manifestations on June 2013 in Brazil in an even more extreme level.

Resources and technological information tools have been enhanced rapidly democratizing the access to information in an unprecedented manner. With the advent of the internet and Web 2.0 tools, the information ceases to concentrate on mass media and large media conglomerates and the possibility of production, selection and interaction to its users is offered, generating new content and information sources. Today, NGOs, social movements and activists can spread their ideas to the world, providing information in their own way. Alternative and independent news agencies emerge to challenge versions of traditional media, such as the NINJA media, Jack Independent Media (Jack Mídia Independente) and several blogs and counterhegemonic websites.

The Brazilian researcher Maria Eugenia Rigitano highlights that activists use the World Wide Web for "being able to spread information and claims without mediation, in order to seek support and mobilize for a cause; create spaces for discussion and exchange of information; organize and mobilize people for online and offline actions and protests" (Rigitano, 2003, p. 3). This type of activism is called digital or online activism. In other words, online activism is the appropriation of the tools available on the internet for articulation, organization, discussion and communication among activists in defense of their demands.

The internet and digital media enable a new understanding and meaning for participation, for democracy, for activism and collective identities. From Web 2.0 tools, characterized by the interaction and collaboration, it is possible to participate in online and offline collective social actions (Rothberg, Luvizotto \& Vanzini, 2014): online, since the internet connectivity structure allows to break down the time and space barrier, allowing any social actor to manifest and deliberate on several issues and social contexts. It is possible to be part of virtual groups that have a motivation, a collective identity and self-represent there, discuss, propose, learn and organize actions. Off-line, since being part of a social group with identity link the actor can post videos, pictures and all kinds of informational content in real time and make public that moment that only the offline participants would be able to know, but with the use of internet it becomes public domain, providing tools for political and social participation.

After discoursing on participation, activism and how digital media support to these social actions, there are two examples of digital information environments that call themselves citizen participation environments: the Vote na Web and Participatório: Observatório Participativo da Juventude. From these examples, it is expected to understand how digital media are changing the scenario of participation and activism in Brazil. 


\section{'VOTE NA WEB' WEBSITE}

The Vote na Web (www.votenaweb.com.br) is a website created in November 2009 to make public Brazilian National Congress bills, where the citizen can know the projects through a brief summary and vote symbolically if he agrees or disagrees with the proposals of the parliamentarians.

The site was developed by a company that focuses on the use of digital technologies for the creation of citizen participation channels in private or government institutions called Webcitizen. One of the main features of the website is the fact that the Brazilian National Congress bills are presented in a more simple and objective language, allowing users to follow the discussions of the House of Representatives and the Senate.

In May 2010 the project was invited to be presented at the Gov 2.0 Expo event in Washington, D.C., which is co-produced by O'Reilly Media Inc. and UBM TechWeb. According to information available on the website itself, the Vote na Web was the only Brazilian initiative invited to attend this event aimed to disseminate internet tools that stimulate the participation of society in politics. After the presentation of the project in Washington, the Webcitizen was invited by the UNO to take part in a workshop on civic engagement in Barcelona, between June 21 and 23, called "Involving citizens in Development Management and Public Governance to achieve the Millennium Development Goals". According to data collected on August 25, 2016, the site has more than 740,000 registered users, more than 10 million and 500,000 votes computed, more than 340,000 comments and 6,340 registered projects. These figures suggest that the website has a significant visibility and enables the interaction between users, as it can be seen by the large number of comments left on bills throughout the site. Many of these comments were made by users who wanted to talk with each other and express an opinion, agreeing or not with the comment made by another citizen.

The Vote na Web is presented as a site of civic and non-partisan engagement, which aims to promote citizen participation and is committed to take the results of civil participation to the Congress. In addition to make public bills in the Brazilian National Congress, the website allows the citizen to vote, symbolically, whether he agrees or not with the proposals of the parliamentarians. The results for Yes or No votes by the users is displayed in graphics. Moreover, it is possible for internet users to compare their votes with each other and with the deputies and senators. Projects are read by analysts, who produce an overview and a summary of each of them. Then they are open to voting by the users and updated with the votes of deputies and senators as soon as they pass by the houses of Congress.

One of its main features are the summaries presented, formulated by analysts from the original bill text - seeking to translate the terms used into a language closer to the one of the public. When the law is appreciated by a vote in the Chamber of Deputies and in the Senate, the website shows a comparison between the vote of legislators and the vote of users.

An important point of Vote na Web website architecture is that it allows the computation of votes to be visualized in a general parameter of users, but also divided into 
categories of gender, age and state. In addition to these possibilities, there is a map of Brazil with the division of votes according to the state that presents the differences of the voting by a scale of colours. Other aspects of the architecture of the said website can be cited, such as the division of the bills presented in categories such as economy, health, labour, cities, culture, sport, transport, among others. On the site, there are also two search tools, including pre-established or keywords filters. Figures 1 and 2 illustrate how the projects are presented on the website.

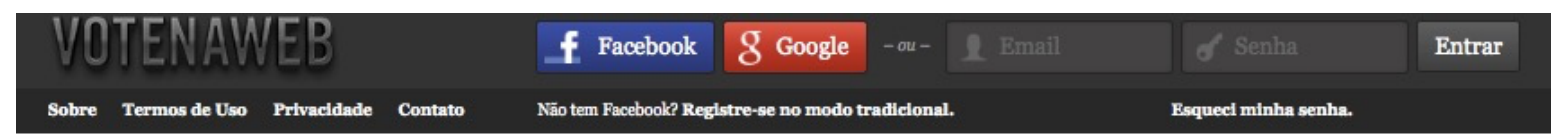

\begin{tabular}{lll|l|} 
Projetos de Lei Arquivo Políticos Ranking & digite aqui o assunto desejado & Q
\end{tabular}

PLC 5069-2013

Punirá, com prisão de 4 a 8 anos, quem anunciar algum método de cometer o aborto.
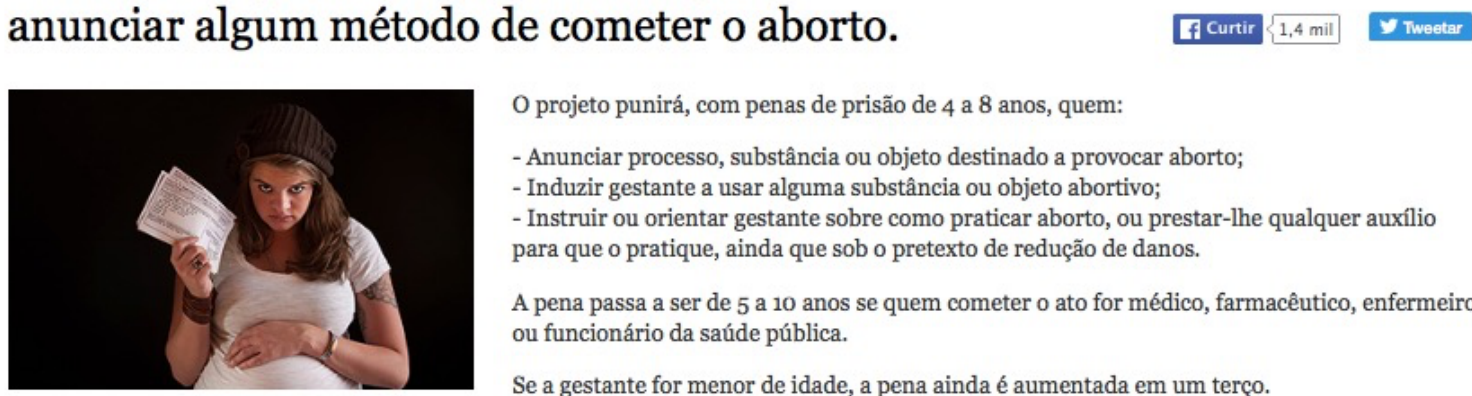

O projeto punirá, com penas de prisão de 4 a 8 anos, quem:

- Anunciar processo, substância ou objeto destinado a provocar aborto;

- Induzir gestante a usar alguma substância ou objeto abortivo;

- Instruir ou orientar gestante sobre como praticar aborto, ou prestar-lhe qualquer auxílio

para que o pratique, ainda que sob o pretexto de redução de danos.

A pena passa a ser de 5 a 10 anos se quem cometer o ato for médico, farmacêutico, enfermeiro ou funcionário da saúde pública.

Se a gestante for menor de idade, a pena ainda é aumentada em um terço.



Segundo o deputado, a campanha internacional para a legalização do aborto tem relação com interesses capitalistas de controlar a natalidade. Para ele, poderosas entidades internacionais estão interessadas em uma política de controle populacional, estimulam o aborto ilegal para reduzir a população mundial. Para o deputado, a lei brasileira deve estar

Tipo: Câmara

Data de apresentaçäo: 27/02/2013

Situação: Em tramitaçắo pronta para evitar este domínio internacional de controle da natalidade.

Categorias:

Votar Sim

Votar Não

1. Ler arquivo original

(V)

Seguir este projeto

Leve este projet
para seu site

Figure 1: Presentation Bill on the Vote na Web site

The Vote na Web aims to be an interactive, informative, participative portal and use Web 2.0 tools to fulfil its proposal. Its design is simple and intuitive, so that users have no major difficulties and obstacles to use it. Figure 3 presents the commenting tool available on each bill. After voting whether the bill is approved or not, the user can classify the project according to six categories: urgent, relevant, brave, unworkable, irrelevant and clueless. Moreover, the citizen can comment his vote and/or dialogue with other users. This tool allows interaction between users, but it is important to note that not all users respect the debate and use the tool in an appropriate way.

\footnotetext{
' Retrieved from http://www.votenaweb.com.br/projetos/plc-5069-2013
} 

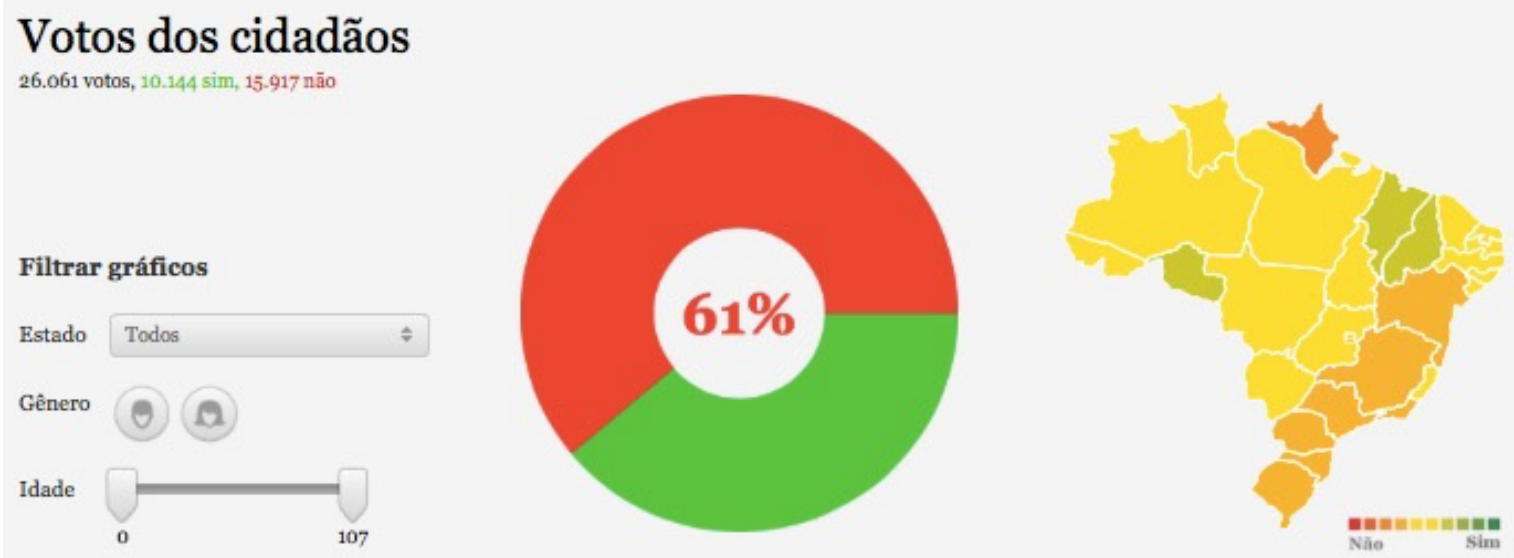

\section{Classificação do cidadão para este projeto}

5.124 classificapọes

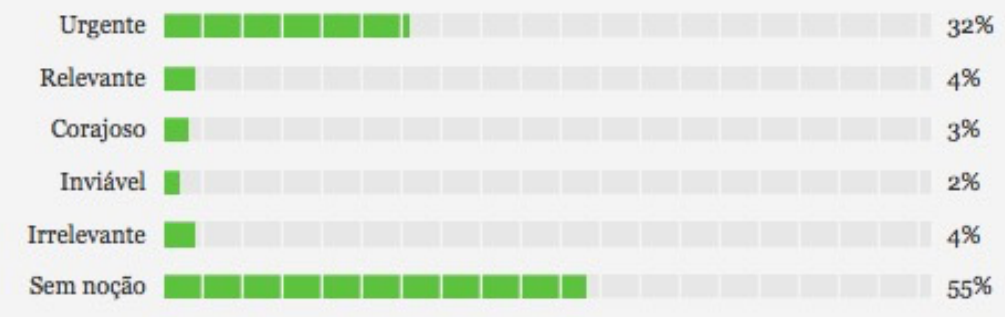

2.196 comentários

Filtrar por: Todos

Figure 2: Presentation of the vote on the Bill, according to citizens - Graphics²

\subsection{6 comentários}

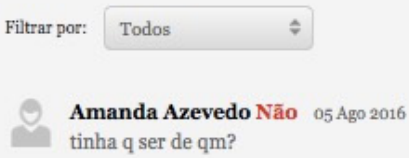

2. Alecson Ribeiro Sim 05 Ago 2016

Pra você ver como até os canalhas como o Eduardo Cunha sāo capazes de acertar as vezes. Agora, se até um canalha defende o que é certo nesse caso, o que isso faz de você que defende o que está errado?

Gustavo Marangao Não 23 Jul 2016 aborto livre já

2. Alecson Ribeiro Sim 30 Jul 2016 Você é a própria definição do abortista: Quando todas as suas mentiras foram expostas, destruídas e humilhadas, você parte pro grito!

Alecson Ribeiro Sim $30 \mathrm{Jul} 2016$

Também! O que mais se pode esperar de um covarde que pede a morte de pessoas inocentes?

Figure 3: Presentation of the vote on the Bill, according to citizens - Commentary ${ }^{3}$

\footnotetext{
${ }^{2}$ Retrieved from http://www.votenaweb.com.br/projetos/plc-5069-2013

3 Retrieved from http://www.votenaweb.com.br/projetos/plc-5069-2013
} 
The information is placed in an objective manner, without too much information and tools are available to speed up access by providing an access link to the bill in full and, if the user is looking for a specific law or parliamentarian, there is also a search engine to help. After login, which can be done through registration or through the social networks Facebook or Google+, it is possible to freely browse the site and use all its resources.

Despite being a site of easy interaction, it is necessary to ask how the summaries of the projects are developed and which is the effectiveness of this information for stimulating and enlightening citizens when he is going to vote and comment. Since the summary is drawn from the subjective logic of someone, it is necessary to ask what elements are representative for this subject, to the point of integrating the summary. It is possible that other elements of the draft law in full, also relevant, are outside of this summary, as it follows the logic of subjective someone and may not reflect the logic of other citizens.

\section{Participatório - Observatório Participativo da JuVentude Website}

Protests and manifestations that took place in Brazil in June and July 2013 were succeeded by several reactions of representatives at different levels of government. At that moment there was a chance that some sectors of public communication materialize their projects. So the Participatório: Observatório Participativo da Juventude website emerged; it is an online platform launched in August 2013 as part of the response of the General Secretariat of the Presidency of the Republic to the protests that took the Brazilian streets in the middle of that year.

Created by the Secretariado Nacional da Juventude (SNJ), organ of General Secretariat of the Presidency of the Republic, with the publication in the Brazil's Official Gazette by Ministerial Act 42, the Participatório (http://participatorio.juventude.gov.br) is an "interactive virtual platform dedicated to the production of knowledge on youth and for the youth itself, through participation and social mobilization" (Article 2 of the Ministerial Act 42 ), which "aims to promote spaces for participation, knowledge production, mobilization and dissemination of content for topics related to youth public policies" (Article 3 ).

The Participatório relates its creation as a response to the recent visibility phenomenon of dissatisfaction of social sectors in public life, as the website could help mediate the dissatisfaction that made people go to the streets, to propose a supposedly organized method to channel political participation and welcome the desire to influence the direction of public policies that matter to young people.

Apparently, according to the underlying logic of the official argument, the Participatório would be another step in the path of participation initiated by the federal government on a range of opportunities that could render other forms of mobilization unnecessary, such as autonomous manifestations observed in the streets (Rothberg, Luvizotto \& Vanzini, 2014). Digital public communication would play the role of catalyzing and organizing youth political expression, thus removing the risk of not submissive manifestations through the provision of allegedly permanent and reliable channels, "the 
Participatório will make public consultations on issues that are on the agenda of $\mathrm{SN}$ J in order to know the opinion of youth and, in this sense, young people may, in fact, to support the actions of the Secretariat and the formulation of public policies" (Participatório, 2013). In other words, by proposing a supposedly organized method to channel political participation and welcoming the desire to influence the direction of public policies that matter to young people, the Participatório could help to pacify the dissatisfaction that took the streets.

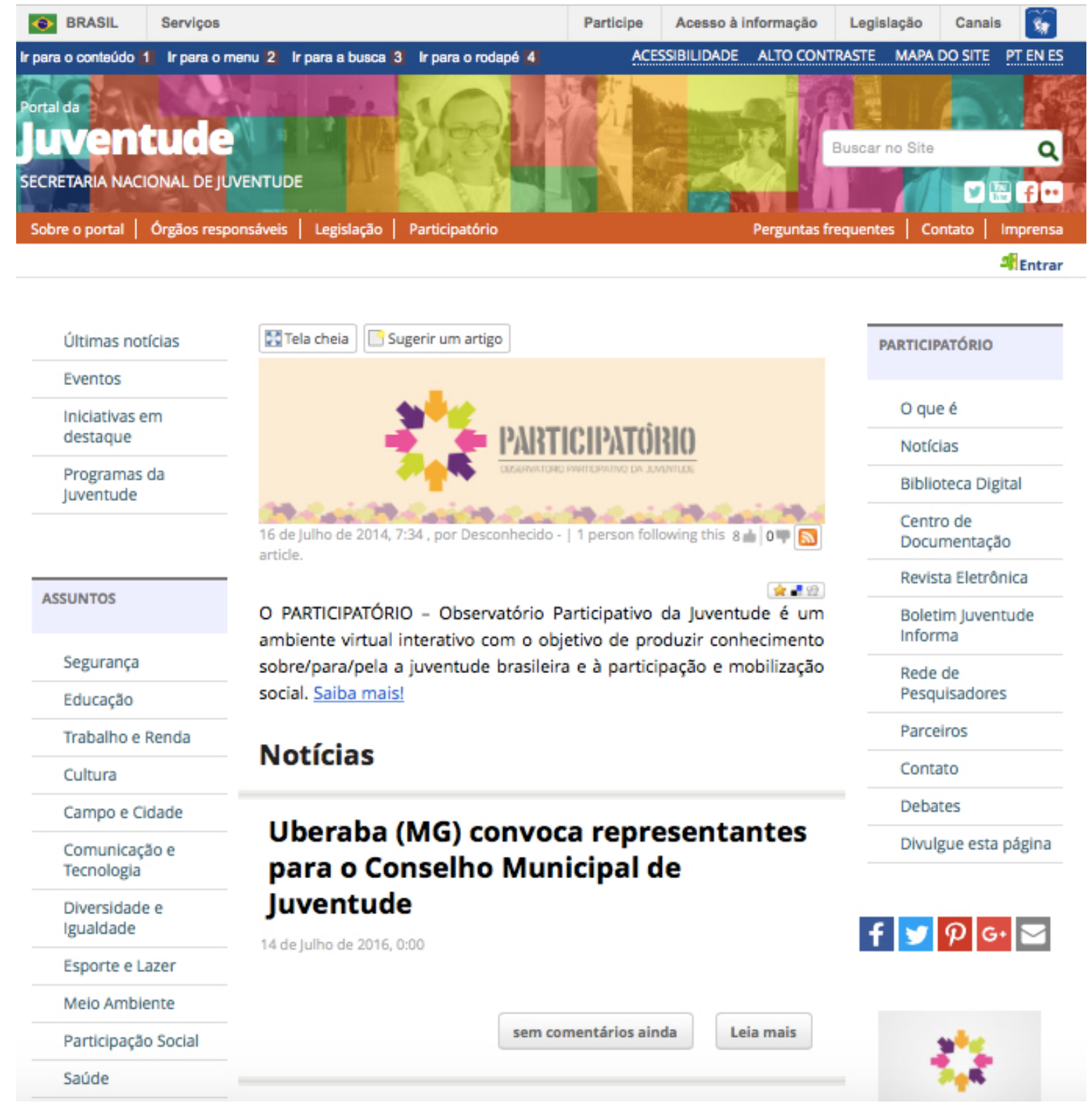

Figure 4: Home page of the website Participatório ${ }^{4}$

The Participatório website features sidebars highlighting three main sections: Participatory: what it is, news, digital library, documentation centre, electronic journal, youth informs bulletin, researchers network, partners, contact, discussions, publicize this page;

\footnotetext{
${ }^{4}$ Retrieved from http://participatorio.juventude.gov.br
} 
Subjects: security, education, labour and income, culture, field and city, communication and technology, diversity and equality, sport and recreation, environment, social participation, health; Content Central: audios, videos, images, publications, legislations, public notices, digital library, statistical data.

In addition, it features a bottom menu with four options, highlighting two of them: Youth portal: about the portal, terms of use, responsible bodies, legislation, participatory, Conjuve, Coijuv, youth alive, youth station, rural youth, international policy; and Social media: facebook, twitter, youtube, flickr, issuu, rss, what is it? Figure 4 presents the website.

Currently, the website has more than 24,000 registered users and 500 divided into 540 communities. In general, sharing resources and exchanging information among users on the website pages is low: many communities have only one member, the one who created the community and there are no interactions. Although the verification of activities and resources used on the website might suggest potential online activism, more active participation in the form of insertion and exchange of content cannot be overlooked as an effective indicator of interest and engagement. Figure 5 shows some communities of the portal:

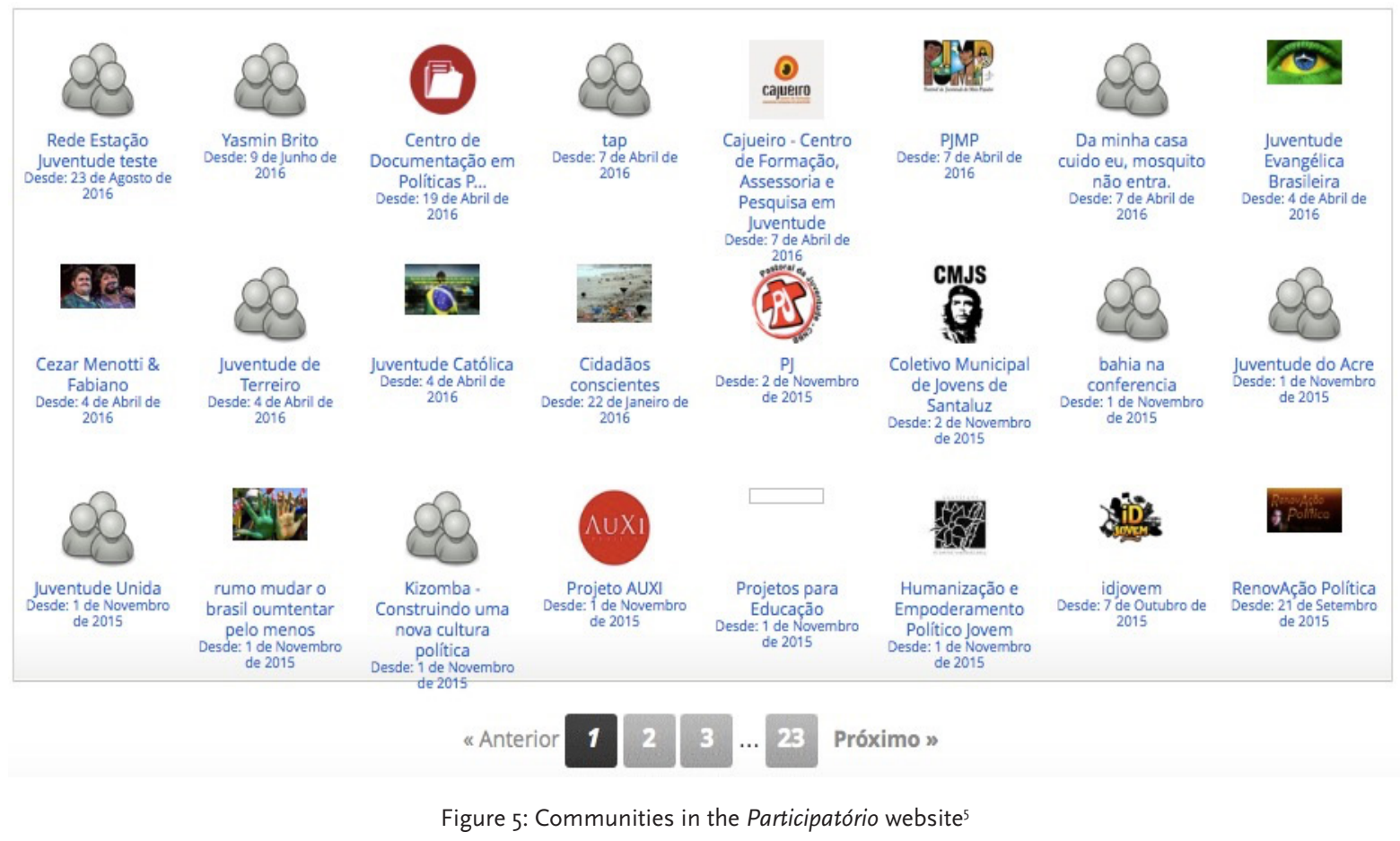

The Participatório is presented as a tool that have benefits from new information and communication technologies (ICT), although improvements to be revealed by future research are necessary. Although the Participatório use new ICT to increase political engagement and participation, with the promise of bringing young people in political and social discussions proposed by the federal government, it is noted that its use was

\footnotetext{
${ }^{5}$ Retrieved from http://juventude.gov.br/search/communities
} 
insufficient to date and this indicates that many efforts should be employed to achieve the objectives that the website wants to achieve.

\section{ConcLusion}

The internet gives users the ability to produce information, not just the opportunity to consume it. It is observed that the online platforms of Web 2.0 and digital media were taken for discussion and debate of several issues and representing the diversity and plurality of social subjects. It is understood that, even in a limited way because of its connectivity infrastructure and aspects of the website's information architecture, such as accessibility and usability, the internet enables participation and real interaction among its users, being a fast and practical way of communication and without geographical and temporal barriers.

Currently, a significant portion of political and social movements and groups articulate their actions through the internet, setting up the so-called online social activism. The network connectivity infrastructure, the current Web feature, the new technologies of information and communication and digital media, prove to be a technological apparatus that enables the communication of social actors in the process of creation, organization and dissemination of their political and social demands.

Governmental and non-governmental initiatives such as the Participatório and Vote na Web are being spread around the world. It is possible to quote, among the several initiatives, the NHS Citizen, from England (https://www.nhscitizen.org.uk), a national program aimed at citizen participation in health-related issues; the Question Bridge, from the United States of America (http://questionbridge.com), an online platform for black men of all ages and backgrounds to express their views on life in America, under multiple aspects; and the Voice of Kibera, from Nairobi, in Africa (http://voiceofkibera. org), a project in partnership with several non-governmental organizations which aims to give voice to residents of Kibera, one of the largest slums in Africa, by aggregating reports, community media, news and information and experience exchange among citizens. Quickly checking the NHS Citizen, Question Bridge and Voice of Kib websites and comparing their architecture with the architecture of the Participatório and Vote na Web websites, it is possible to realize that all of them present Web 2.0 tools and, in its genesis, were developed to promote the participation of citizens on matters in the most diverse social instances. They have significant access, but as in the Brazilian examples, it is observed that conversation tools could be better used.

The digital information environments must be designed and programmed in order to assist the interactions between subjects. So, in addition to allow free conversation among users, they should provide tools to assist in the participation process, being appropriate environments for social movements and activists to express their demands and extend their range and discussions. These tools are closely related to the architecture of the website and the information provided to stimulate discussion, since the participant must also have access to information that enables criticism and decision-making. This 
study suggests that, in the Brazilian case, the Web 2.0 technologies assist the process of political and social participation, serving of social movements and activists if used in their totality, with the full potential of the tools of interaction and collective construction of knowledge. Nevertheless, none of this have an effect on the participation if there is not the will and the mobilization of citizens to participate.

It is concluded that the websites presented have limitations and that online tools are not used in their full potential. But, from the context of citizenship and online participation, it is possible to verify that the architecture of websites promotes participation, even without civic engagement, and that the communicative and interactive processes involved in this online platform are a step towards a broader citizen practice. First and foremost, we need to develop a culture of participation and strengthen the mechanisms of participation that exist in our society, in schools, in neighbourhood associations, in civil society organizations and in all government bodies.

\section{BibliogRAPHIC REFERENCES}

Bordenave, J. D. (1983). O que é participação. São Paulo: Brasiliense.

Castells, M. (2006). A sociedade em rede. São Paulo: Paz e Terra.

Demo, P. (1996). Participação é conquista: noções de política social participativa. São Paulo: Cortez.

Gohn, M. da G. (2003). Movimentos sociais no início do século XXI: antigos e novos atores sociais. Petrópolis: Vozes.

Luvizotto, C. K. (2015). A disseminação da tradição e a preservação da memória coletiva na era digital. Liinc em Revista, 11, 14-27.

Luvizotto, C. K., Carniel, F. (2013). Educação a distância na sociedade da informação: reflexões acerca dos processos de comunicação, ensino e aprendizagem na sala de aula virtual. Conexão: Comunicação $e$ Cultura, 12, 13-40.

Machado, J. A. S. (2007). Ativismo em rede e conexões identitárias: novas perspectivas para os movimentos sociais. Sociologias. 9(18), 248-285.

Mansbridge, J. J. (1990). Beyond self-interest. Chicago: The University of Chicago Press.

Moraes, D. de (2000). Comunicação virtual e cidadania: movimentos sociais e políticos na Internet. Revista Brasileira de Ciências da Comunicação, XXIII(2), 142-155.

Pereira, M. A. (2011). Internet e mobilização política - os movimentos sociais na era digital. In Anais do IV Encontro da Associação Brasileira de Pesquisadores em Comunicação e Política. Retrieved from http://www. compolitica.org/home/?page_id=485\#gt4.

Peruzzo, C. M. K. (2013). Movimentos sociais, redes virtuais e mídia alternativa no junho em que "o gigante acordou". Matrizes, 7(2), 73-93.

Rigitano, M. E. C. (2003). Redes e ciberativismo: notas para uma análise do centro de mídia independente. Retrieved from http://www.bocc.ubi.pt/pag/rigitano-eugenia-redes-e-ciberativismo.pdf.

Rothberg, D., Luvizotto, C. K. \& Vanzini, K. V. (2014). As revoltas e seu impacto sobre a comunicação pública: o potencial do Observatório Participativo da Juventude Liinc em Revista, 10(1), 227-240. 
Scherer-Warren, I. (2006). Das mobilizações às redes de movimentos sociais. Sociedade e Estado, 21(1), 109-130.

Valente, C. \& Mattar, J. (2007). Second Life e Web 2.o na educação: o potencial revolucionário das novas tecnologias. São Paulo: Novatec Editora.

Weber, M. (1978). Ação e relação social. In M. M. Foracchi \& J. S. Martins (Eds.), Sociologia e sociedade (pp. 139-144). Rio de Janeiro: LTC.

Young, I. M. (2001). Activists challenge deliberative democracy. Political Theory, 29(2), 670-690.

\section{BIOGRAPHICAL NOTE}

Caroline Kraus Luvizotto holds a PhD in Social Sciences by UNESP - Universidade Estadual Paulista Júlio de Mesquita Filho. She is a lecturer at the Faculty of Architecture, Arts and Communication of FAAC/UNESP - Bauru Campus, and she is a member of the Communication Post-Graduation programme at FAAC/UNESP and also the head of the Communication and Social Movements research group - ComMov. Email: caroline@faac.unesp.br

Universidade Estadual Paulista Júlio de Mesquita Filho

Programa de Pós-Graduação em Comunicação. Bauru - SP

Av. Eng Luiz Edmundo Carrijo Coube, $n^{\circ} 14-01$

Bairro: Vargem Limpa

Bauru - SP, 17033-360, Brasil

* Submitted: 13-03-2016

* Accepted: 15-04-2016 